\title{
Characterization of prostaglandin $E$ receptor subtypes involved in the relax- ation of rabbit penile corpus cavernosum smooth muscle
}

\author{
Minoru SATO* and Masahito KaWATANI \\ Department of Neurohysiology, Akita University School of Medicine, Akita 010-8543; and *Department of Life and Culture, Akita \\ Keizaihouka University Junior College, 46-1 Shimokitate Sakura Morisawa, Akita 010-8515 Japan.
}

(Received 1 September 2004; and accepted 29 September 2004)

\begin{abstract}
Prostaglandin E (PGE) induces the penile erection in the mammalians. Receptors for PGE were characterized to 4 different subtypes (EP1-4). The effects of agonists for EP1-4 receptors were studied on phenylephrine $(\mathrm{PE}, 1 \mu \mathrm{M})$-induced contractions in the rabbit penile corpus cavernosum smooth muscle. The EP4 receptor agonist, ONO-AE1-329 $(1 \mathrm{pM}-10 \mu \mathrm{M})$, markedly relaxed the pre-contracted smooth muscle strips in a concentration-dependent fashion $(-65 \pm 16 \%$ relaxation at $10 \mathrm{nM})$. The EP2 receptor agonists, ONO-AE1-259-01 $(1 \mathrm{nM}-10 \mu \mathrm{M})$ or butaprost $(1 \mathrm{nM}-10$ $\mu \mathrm{M})$, also relaxed the smooth muscle strips in a concentration dependent fashion $(-58 \pm 10 \%$ relaxation at $10 \mu \mathrm{M}$ or $-53 \pm 10 \%$ relaxation at $10 \mu \mathrm{M})$. The EP1 receptor agonist, ONO-DI-004 $(0.01-10 \mu \mathrm{M})$, increased the contractility in the smooth muscle strips. A $12 \pm 6 \%$ increase was observed with $10 \mu \mathrm{M}$ of the agonist. The EP3 receptor agonist, ONO-AE-248 (0.01-10 $\mu \mathrm{M})$, however, did not alter the contractility of the smooth muscle strips. The selective EP4 receptor antagonist, ONO-AE3-208 $(0.1 \mu \mathrm{M})$, inhibited a relaxant response to ONO-AE1-329 (the EP4 receptor agonist) but did not affect a relaxant response to ONO-AE1-259-01 (the EP2 receptor agonist). It is likely that the relaxant effect of ONO-AE1-329 acts on the EP4 receptor. Neither a nitric oxide synthase (NOS) inhibitor, L-NAME $(300 \mu \mathrm{M})$, nor a soluble guanylyl cyclase inhibitor, ODQ $(30 \mu \mathrm{M})$, affected the relaxant responses to ONO-AE1-259-01 $(0.1-10 \mu \mathrm{M})$ or ONOAE1-329 $(0.01 \mathrm{nM}-1 \mu \mathrm{M})$. In summary, EP4 and/or EP2 receptors mediate relaxations in rabbit corpus cavernosum smooth muscle, and the EP4 relaxant system is higher in relaxant potency than the EP2 system. Furthermore, the relaxations are independent from a nitric oxide (NO)/cGMP signalling pathway.
\end{abstract}

Prostaglandin E2 (PGE2) is known to elicit contraction and/or relaxation of various smooth muscles in vitro (11). The receptor of prostaglandin (EP) has been divided into four subtypes (EP1-4 receptors) using pharmacological (12) and receptor cloning studies $(13,24)$. EP1 receptors mediate the contrac-

Correspondence to Dr. M. Kawatani

Department of Neurophysiology, Akita University, School of Medicine, 1-1-1 Hondo Akita-city, 010-8543, JAPAN

Tel: +81-18-884-6072, Fax: +81-18-836-2605

E-mail: Kawatani@med.akita-u.ac.jp tion of smooth muscle in various organs (13). EP2 receptors mediate smooth muscle relaxation in bronchial, vascular and gastrointestinal systems (26). In addition, EP3 receptors are involved in smooth muscle contraction (31) and EP4 receptors mediate vascular smooth muscle relaxation $(2,6)$. Transfection of recombinant receptors into Chinese hamster ovary cells has revealed that each receptor is G-proteincoupled with a different signal transduction system (24).

It has been reported that PGE1 reduces noradrenaline-induced contractions in human penile corpus cavernosum $(3,17)$. Intracavernous injection of 
PGE1 also induces penile erection in humans and monkeys $(1,30)$. PGE1 has been used as intraurethral therapies for erectile dysfunction (28). Moreover, EP2 and EP4 receptors have been identified in human corpus cavernosum (22). A recent report showed that butaprost, the EP2 receptor agonist, caused relaxation of human corpus cavernosum smooth muscle (5). However, it has not been well established as to what the EP receptor subtypes function in regulating cavernosal smooth muscle contractility.

It has been established in last two decades that NO/cGMP cascades have been thought to be a major signal transduction pathway in the physiological penile erection $(3,4)$. In contrast, PGE1 elicits relaxation of corpus cavernosal smooth muscle by stimulating adenylyl cyclase to increase intracellular concentrations of cAMP $(5,10,21,29,36)$. Since repeated PGE1 treatment enhances erectile responses to nerve stimulation in the rat penis by up-regulating constitutive NOS isoforms, the NO/cGMP signalling pathway might be partly involved in PGE1-induced relaxation of the cavernosal smooth muscle (15).

In this study, to characterize the EP receptor subtypes involved in the regulation of contractility of rabbit penile corpus cavernosum smooth muscle, we examined the effects of agonists for EP1-4 receptors on the tissue smooth muscle strips.

\section{MATERIALS AND METHODS}

Corpus cavernosum preparations and tension measurements. The methods for tissue preparations and tension measurements were performed in accordance with our previous report (32). Male Japanese white rabbits $(2.5-4.0 \mathrm{~kg})$ were anesthetized with urethane $(0.5 \mathrm{~g} / \mathrm{kg})$ by intraperitoneal injection. Then a cyclooxygenase inhibitor, diclofenac $(2-4 \mathrm{mg} / \mathrm{kg})$, was injected intravenously to prevent the release of endogenous cyclooxygenase products due to surgical operation. After $20 \mathrm{~min}$, penises were surgically dissected at the level of attachment of corporal body to the ischum and were quickly placed in a HEPESbuffered solution (HBS). The HBS (composition, $\mathrm{mM}: \mathrm{NaCl} 135.5, \mathrm{KCl} 5.9, \mathrm{CaCl}_{2} 1.8, \mathrm{MgCl}_{2} \cdot 6 \mathrm{H}_{2} \mathrm{O}$ 1.2, glucose 11.0 and HEPES 10.0, $\mathrm{pH} 7.4$ ) was bubbled with $100 \% \mathrm{O}_{2}$. The corpus cavernosal tissues were carefully dissected free from the surrounding tunica albuginea. They were then longitudinally sectioned into strips preparations $(1.5 \times 1.5$ $\times 6 \mathrm{~mm}$ ) for tension measurements. The tissue strips were placed vertically in a thermostatically con- trolled organ bath $\left(37^{\circ} \mathrm{C}, 10 \mathrm{ml}\right)$ which was filled with $100 \% \mathrm{O}_{2}$-bubbled $\mathrm{HBS}$, a perfusing solution. Contractile tension of the tissue strips were isometrically measured by a force transducer (Type 45196A; GE Marquette Medical Sys. Japan Ltd., Tokyo, Japan) with an amplifier (Type 1829; GE Marquette Medical Sys. Japan Ltd.) and recorded on a pen recorder (R-62; Rikadenki Kogyo CO, Ltd., Tokyo, Japan). The tension of the strips was adjusted to $0.2-0.4 \mathrm{~g}$ (a basal tone) and allowed to equilibrate for $1-2 \mathrm{~h}$ before the experiments. The HBS was changed at $30 \mathrm{~min}$ after mounting and also at least three times after each drug test.

The protocols for animal experimentation described in this paper were previously approved by the Animal Research Committee, Akita University. All subsequent animal experiments adhered to the "Guidelines for Animal Experimentation" of the University.

Experimental protocols. Rabbit corpus cavernosum tissue strips were pre-contracted by administrating the selective $\alpha 1$-adrenoceptor agonist, PE $(1 \mu \mathrm{M})$, into a bath. After the contraction reached to a stable state (a plateau or a gradually relaxing state after a maximum level), selective agonists for EP1-4 receptors were applied in a cumalative fashion. An increase in tension was calculated from the difference between the level of tension during PE application and a resting level. Relaxation or contraction of rabbit corpus cavernosum tissue strips referred to changes in contractile tension induced by PE. The degree of relaxation or contraction was expressed as a percentage of an increase or decrease of the $1 \mu \mathrm{M}$ PE-induced contraction. Log concentration-response curves for EP receptor subtype agonists were presented in the figs.

In the experiments of the effects of an EP4 receptor antagonist and the inhibitors of NOS and guanylyl cyclase on the responses to EP2 or EP4 receptor agonists, the drugs were added to a bath at $10 \mathrm{~min}$ before PE treatment. All estimates of the effects of the drugs were made by comparing the agonist effect with concurrent time controls treated with the same agonist in the presence of the appropriate concentration of an antagonist vehicle. The inhibitions by the drugs were calculated as a test/control and expressed as a percentage.

Drugs and chemicals. ONO-DI-004, ONO-AE1-25901, ONO-AE-248, ONO-AE1-329, ONO-AE3-208 were gifts from Ono Pharmaceutical Co. Ltd. (Osaka, Japan). Butaprost (methyl-3-hydroxy 2-[4-hydroxy- 
4-(1-propylcyclobutyl)-1-butenyl]-5-oxo-cyclopentaneheptanoate), diclofenac sodium and PE (phenylephrine hydrochloride) were purchased from Sigma Chemical Co. (St. Louis, MO, U. S. A.). HEPES (2-[4-(2-Hydroxylethyl)-1-piperazinyl] ethanesulfonic acid), L-NAME (NG-Nitro-L-arginine methyl ester) and ODQ (1H [1, 2, 4-] Oxadiazolo [4, 3-a] quinoxalin-1-one) were purchased from Dojindo Laboratories (Kumamoto, Japan). Diclofenac was dissolved in ethanol and then diluted by $0.9 \% \mathrm{NaCl}$ solution. PE was soluted in distilled water. The other drugs were dissolved in dimethyl sulfoxide and the solutions were stored at $-20^{\circ} \mathrm{C}$.

Statistical analysis. Statistical analysis was made by the Mann-Whitney test. $\mathrm{P}<0.05$ was used as an indicator of statistical significance. All averaged data have been expressed as a mean \pm standard error of the mean (S. E. M.).

\section{RESULTS}

Effects of agonists for EP1-4 receptors on penile corpus cavernosum smooth muscle contractility

The EP4 receptor agonist, ONO-AE1-329 (1 pM-10 $\mu \mathrm{M})$, attenuated contractile tension of cavernosal smooth muscle strips pre-contracted with PE $(1 \mu \mathrm{M})$ (Figs. 1A and 2). The relaxant response started at 0.1 $\mathrm{nM}(-10 \pm 7 \%, \mathrm{n}=16, \mathrm{P}<0.005)$, then proceeded in a concentration-dependent fashion and showed -65 $\pm 16 \%$ relaxation at $10 \mathrm{nM}(\mathrm{n}=16, \mathrm{P}<0.005)$, and finally reached to a basal level of tension at $1 \mu \mathrm{M}$ $(-97 \pm 2 \%)(\mathrm{EC} 50=4.6 \mathrm{nM})$. The relaxant response was detectable within 1 min after the application.

The EP2 receptor agonist, ONO-AE1-259-01 (1 $\mathrm{nM}-10 \mu \mathrm{M})$, induced a relaxant response in the precontracted smooth muscle strips (Figs. 1B and 2). The relaxant response started at $0.1 \mu \mathrm{M}(-7 \pm 5 \%$, n $=16, \mathrm{P}<0.01)$, then became larger in a concentration-dependent fashion and showed $-18 \pm 7 \%$ relaxation at $1 \mu \mathrm{M}(\mathrm{n}=16, \mathrm{P}<0.005)$ and $-58 \pm 10 \%$ relaxation at $10 \mu \mathrm{M}(\mathrm{n}=16, \mathrm{P}<0.005)$. The relaxant response was detectable within $1 \mathrm{~min}$ after the application. Similarly, another EP2 receptor agonist, butaprost $(1 \mathrm{nM}-10 \mu \mathrm{M})(16)$, exerted a relaxant response (Fig. 2). The response started at $1 \mu \mathrm{M}(-15 \pm$ $8 \%, \mathrm{n}=4, \mathrm{P}<0.05)$, then concentration-dependently proceeded and showed $-53 \pm 10 \%$ relaxation at 10 $\mu \mathrm{M}(\mathrm{n}=4, \mathrm{P}<0.05)$. There was no statistical difference in relaxant potency between the two EP2 receptor agonists $(\mathrm{n}=4, \mathrm{P}>0.05)$.

The EP1 receptor agonist, ONO-DI-004 (0.01-10 $\mu \mathrm{M})$, increased the contractile tension of cavernosal smooth muscle strips pre-contracted with PE (Figs. $1 \mathrm{C}$ and 2). The contractile response occurred by 12 $\pm 4 \%$ of PE-induced contraction at $10 \mu \mathrm{M}(\mathrm{n}=7$, $\mathrm{P}<0.05)$. The response was detectable within $3 \mathrm{~min}$ after the application.

The EP3 rceptor agonist, ONO-AE-248 (0.01-10 $\mu \mathrm{M})$, did not alter the pre-contracted smooth muscle strips $(n=15)$ (Fig. 2).

Effects of the EP4 receptor antagonist on relaxant responses to agonists for EP4 or EP2 receptors

We tested the effect of the EP4 receptor antagonist, ONO-AE3-208 $(0.1 \mu \mathrm{M})$, on the relaxant responses to agonists for EP4 or EP2 receptors. The relaxant response to the EP4 receptor agonist, ONO-AE1-329 $(0.01 \mathrm{nM}-1 \mu \mathrm{M})$ (control, $\mathrm{n}=4)$, was attenuated by treatment with the antagonist $(\mathrm{n}=4, \mathrm{P}<0.05)$ (Fig. $3 \mathrm{~A})$. The antagonist diminished a relaxant response to the $1 \mu \mathrm{M}$ EP4 receptor agonist from complete inhibition to $-28 \pm 9 \%$ inhibition. This is a statistically significant difference. The relaxant response to
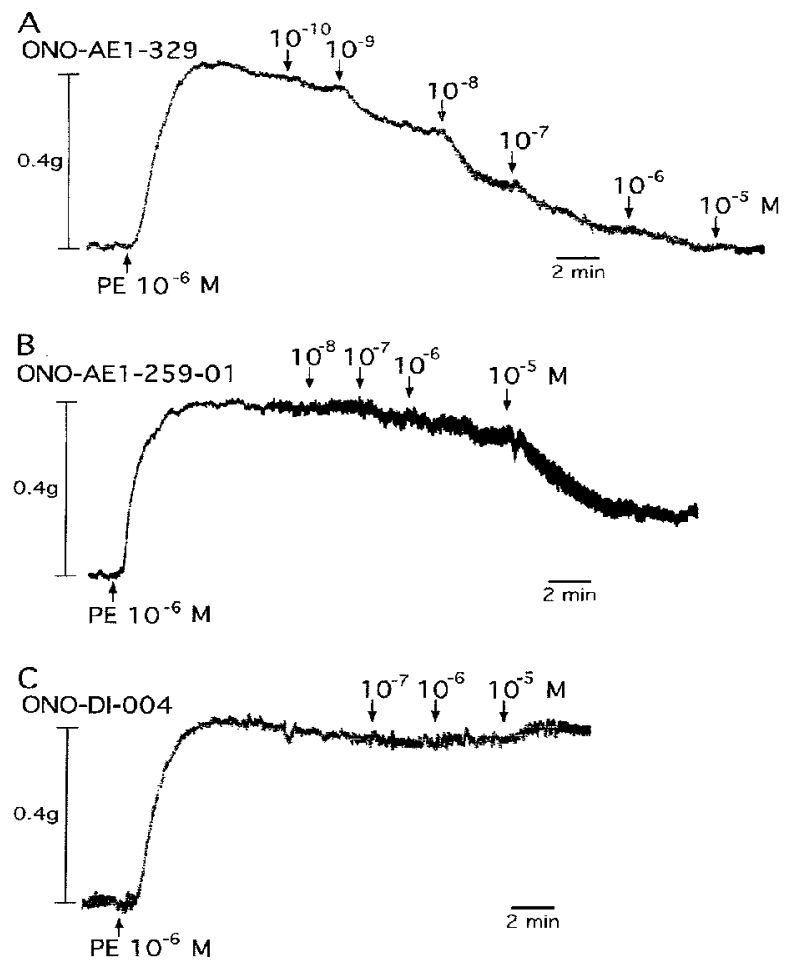

Fig. 1 Representative relaxant and/or contractile responses to the EP4 receptor agonist, ONO-AE1-329 (0.1 nM-10 $\mu \mathrm{M})(\mathrm{A})$, the EP2 receptor agonist, ONO-AE1-259-01 (10 $\mathrm{nM}-10 \mu \mathrm{M})(\mathrm{B})$ and the EP1 receptor agonist, ONO-DI-004 $(0.1-10 \mu \mathrm{M})(\mathrm{C})$ in the rabbit penile corpus cavernosum smooth muscle strips contracted with PE $(1 \mu \mathrm{M})$. Cumulative concentration-dependent responses to agonists for three EP receptor subtypes are shown. 


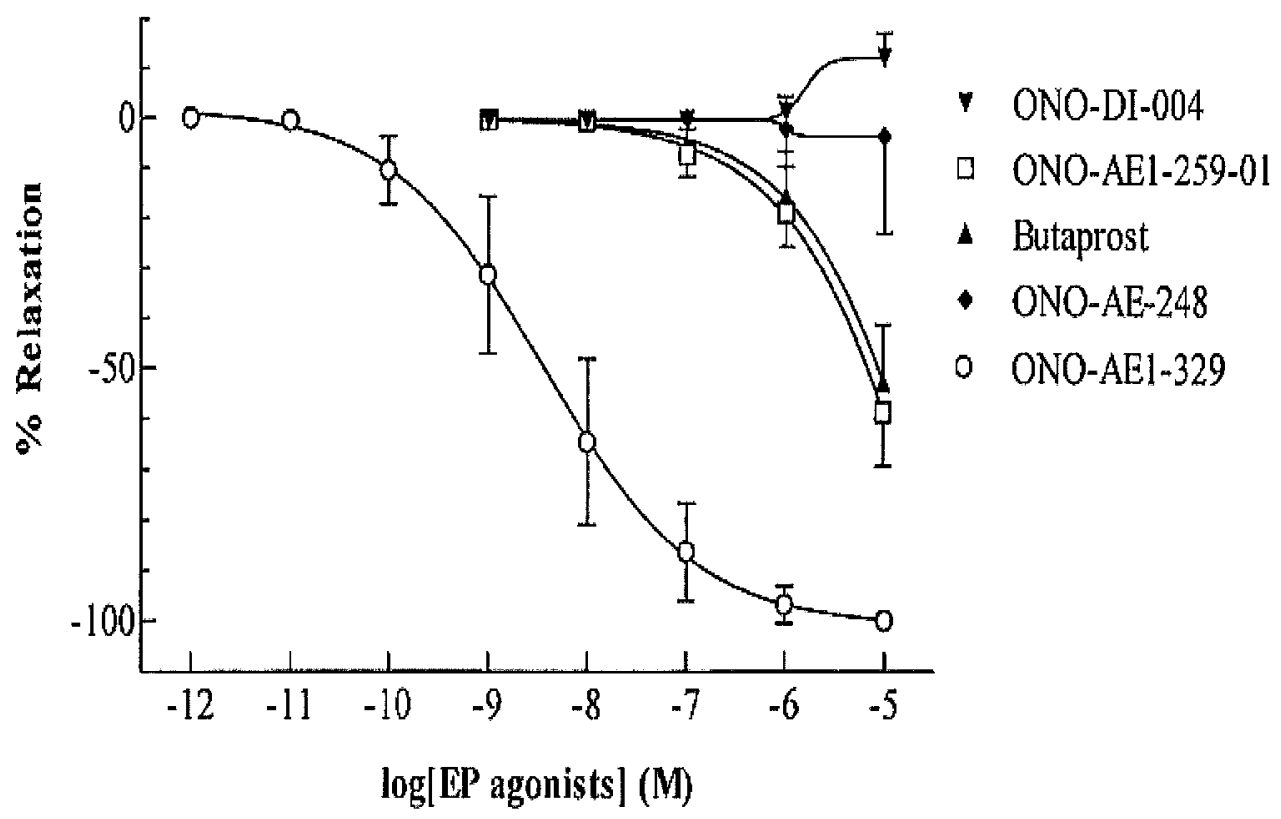

Fig. 2 Summary of concentration-dependent responses to agonists for EP1-4 receptors in the rabbit cavernosal smooth muscle strips. Data of the EP1 receptor agonist, ONO-DI-004 $(n=7)$, the EP2 receptor agonist, ONO-AE1-259-01 $(n=16)$ and butaprost $(n=4)$, the EP3 receptor agonist, ONO-AE-248 $(n=15)$, and the EP4 receptor agonist, ONO-AE1-329 $(n=$ $16)$, are expressed as mean of the percentage of PE-induced contraction shown by vertical lines.

the EP2 receptor agonist, ONO-AE1-259-01 (0.1-10 $\mu \mathrm{M})$, was not altered by the antagonist $(n=4)$ (Fig. 3B).

Effects of L-NAME and $O D Q$ on relaxant responses to agonists for EP4 or EP2 receptors

We evaluated the effects of the NOS inhibitor, L-NAME $(300 \mu \mathrm{M})$, or the soluble guanylyl cyclase inhibitor, ODQ $(30 \mu \mathrm{M})$, on the EP4 or EP2 relaxant responses (14). The application of L-NAME or ODQ before PE treatment induced a slight contraction $(14 \pm 5 \%)$ from a basal level of tension of the cavernosal smooth muscle. Neither L-NAME nor ODQ modified the relaxant responses to the EP4 receptor agonist $(0.01 \mathrm{nM}-10 \mu \mathrm{M})($ Fig. $4 \mathrm{~A})$ or ONOAE1-259-01 (0.1-10 $\mu \mathrm{M})$ (Fig. 4B).

\section{DISCUSSION}

PGE1 induces cavernosal smooth muscle relaxation (3), and EP1-4 receptor mRNAs are present in human cavernosal smooth muscle (22). However, the functions of the EP1-4 receptors in the cavernosal smooth muscle have not been clearly understood. The present studies provided the evidence for the functions of the receptors as follows: in rabbit corpus cavernosum smooth muscle, agonists for EP4 or EP2 receptors induced relaxations, and the EP4 re- ceptor agonist was profoundly higher in relaxant potency than the EP2 receptor agonists. Reversely, the EP1 receptor agonist elicited a slight contraction, and the EP3 receptor agonist did not alter the contractility.

The two EP2 receptor agonists, ONO-AE1-259-01 and butaprost, caused relaxant responses with the respective relaxation of $-58 \pm 10 \%$ and $-53 \pm 10 \%$ at $10 \mu \mathrm{M}$. The data suggest that the EP2 receptor mediates relaxation. Their relaxant potencies are relatively close to a recently-reported relaxant potency of butaprost observed in human penile trabecular smooth muscle (about $-80 \%$ relaxation at $10 \mu \mathrm{M}$ ) (5).

The EP4 receptor agonist, ONO-AE1-329, induced a relaxant response in a concentration-dependent fashion, suggesting that EP4 receptors on rabbit cavernosal smooth muscle mediate relaxation. The present study also showed that the concentrations of agonists needed to produce about $-60 \%$ relaxation were $10 \mathrm{nM}$ for the EP4 receptor agonist and $10 \mu \mathrm{M}$ for the two EP2 receptor agonists. The present results indicated that the EP4 receptor agonist is about 1000 fold higher in relaxant potency than the two EP2 receptor agonists. This finding suggests that the EP4 receptor-mediated relaxant system is higher in relaxant potency than the EP2 relaxant system.

The high EP4 relaxant potency has been also de- 

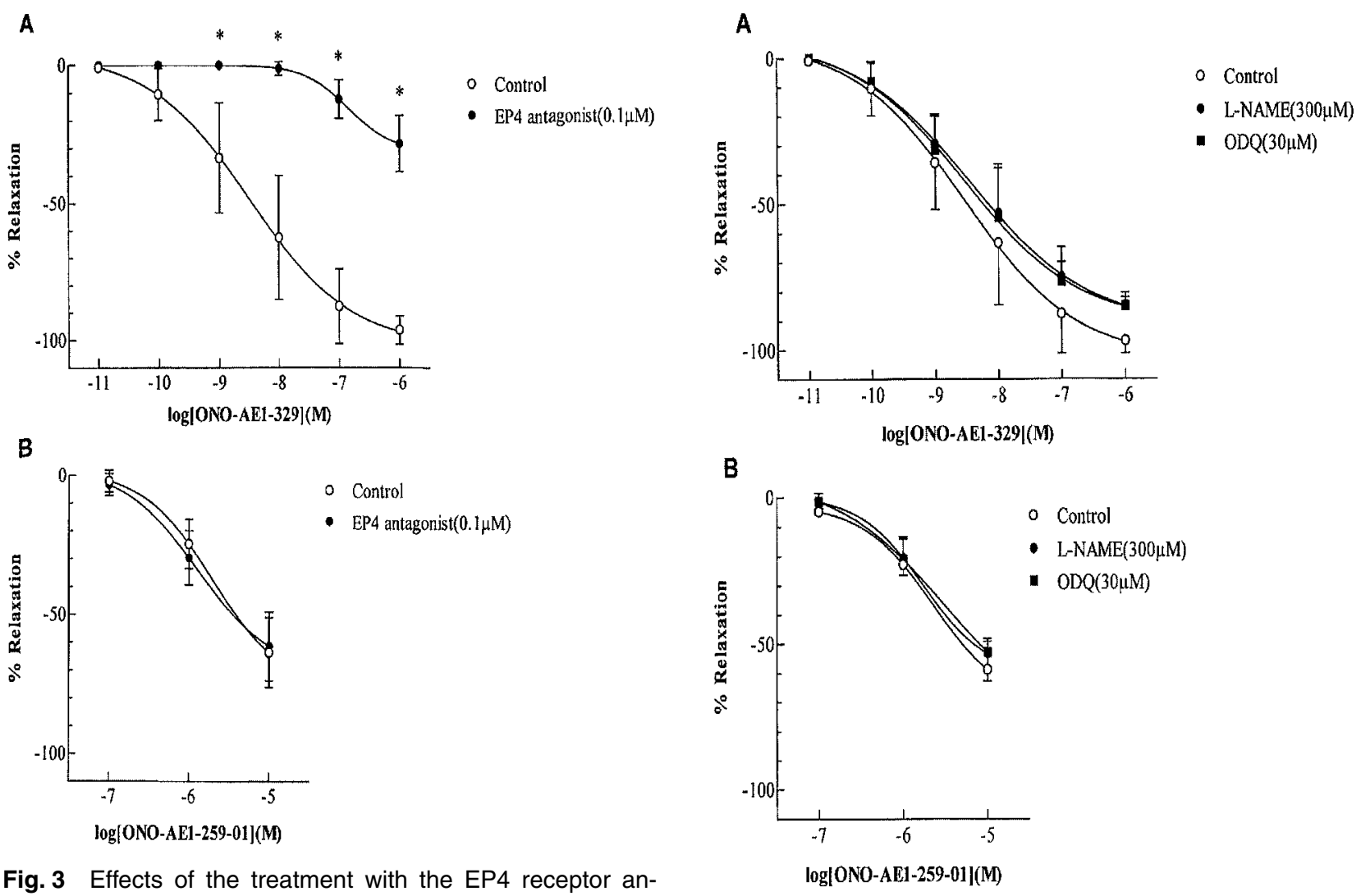

Fig. 3 Effects of the treatment with the EP4 receptor antagonist, ONO-AE3-208, on the relaxant responses to the EP4 receptor agonist, ONO-AE1-329 (A) and the EP2 receptor agonist, ONO-AE1-259-01 (B) in cavernosal muscle strips contracted with PE. At 10 min before contraction with $\mathrm{PE}$, the EP4 antagonist was applied to a bath at a final concentration of $0.1 \mu \mathrm{M}$. Asterisks indicate a statistically significant difference with the corresponding control value. ${ }^{*} \mathrm{P}<0.05$ compared to the control values. Controls mean the relaxations induced by EP2 and/or EP4 receptor agonists in the absence of the antagonist.

scribed in the vascular system. In piglet saphenous vein ring preprations, the EP4 relaxant system $(\mathrm{EC} 50<0.3 \mathrm{nM})$ is more sensitive than the EP2 system $(\mathrm{EC} 50=3-30 \mathrm{nM})(11)$. In the rat renal afferent arteriole, PGE2-induced vasodilation was mostly mediated by the EP4 receptor (35). Possible explanations for the reason of the high EP4 relaxant potency are as follows: first, since there is no difference in binding affinity between the EP2 receptor agonist, ONO-AE1-259-01, to the mouse EP2 receptor expressed on Chinese hamster ovary cells and EP4 receptor agonist, ONO-AE1-329, to EP4 receptor $(19,34)$, the EP4 receptor might be more present than the EP2 receptor on the rabbit cavernosal smooth muscle. In fact, whereas the EP4 receptor and its mRNA have been found in almost all mouse tissues examined, EP2 mRNA is the least

Fig. 4 Effects of L-NAME and ODQ on the relaxant responses to the EP4 receptor agonist, ONO-AE1-329 (A), and the EP2 receptor agonist, ONO-AE1-259-01 (B). At 10 min before contraction, L-NAME and ODQ were added to a bath at final concentrations of $300 \mu \mathrm{M}$ and $30 \mu \mathrm{M}$, respectively. Controls mean the relaxations induced by EP2 and/or EP4 receptor agonists in the absence of the inhibitors.

abundant in the four EP receptor subtypes (24). Second, the EP4 receptor is coupled to a more highly tuned second messenger system (37).

The present data, which showed that the EP4 receptor antagonist, ONO-AE3-208, reduced a relaxant response to $1 \mu \mathrm{M}$ of EP4 receptor agonist from $-100 \%$ relaxation to $-28 \pm 9 \%$, indicate that the antagonist partly inhibited the relaxant response to the EP4 receptor agonist. This finding confirmed that the EP4 receptor agonist acted on the EP4 receptors. The present data also indicated that the EP4 receptor antagonist did not completely inhibit the relaxant response with the higher dose of the EP4 receptor agonist that was tried. This might be due to the lack of a high dose of EP4 antagonist. Since it has been known that the binding affinity of the EP4 receptor agonist to the mouse EP2 receptor is about one twohundredths of the agonist to the mouse EP4 receptor (34), there is little possibility that the EP4 receptor 
agonist could partly activate the EP2 receptor at 1 $\mu \mathrm{M}$. Also the binding affinity of the EP2 receptor agonist to the EP4 receptor is about one two-thousandths of the agonist to the EP2 receptor (34). Together with the present finding that the EP4 relaxant potency is 1000 fold higher than the EP2 relaxant potency, it is assumed that the EP2 receptor agonist might partly activate the EP4 receptor at $10 \mu \mathrm{M}$.

The principal intracellular messengers involved in cavernosal smooth muscle relaxation are cAMP and cGMP $(4,7)$. Major physiological penile erection occurrs through parasympathetic nerve excitation, which stimulates NO release from both the nonadrenergic noncholinergic nerve and the trabecular endothelium (3). The NO diffuses into the smooth muscle cells, where it activates the soluble guanylyl cyclase to increase cGMP $(3,9)$. However, the present results displaying that the relaxant responses to agonists for EP4 and/or EP2 receptors were not affected by treatments with L-NAME $(300 \mu \mathrm{M})$ or ODQ $(30 \mu \mathrm{M})$, suggest that the NO/cGMP signalling pathway is not involved in the relaxations mediated by EP4 and/or EP2 receptors. Since the high concentrations of these inhibitors exhibited an inhibitory effect on isoprenaline-induced relaxation in rat aortic rings (14), high doses of them were used in the present study. The present finding that EP4 and/ or EP2 relaxant responses did not involve the NO/ cGMP signalling pathway is indirectly consistent with a recent report that the treatment of human cavernosal tissue with PGE1 caused a concentration-dependent increase in cAMP tissue levels, whereas the cGMP levels remained unchanged (5). Both EP4 and EP2 receptors have been shown to be coupled to one of the GTP binding protein Gs, and are thought to produce vasodilation by stimulating the production of cAMP (11). Together with, the present cavernosal smooth muscle relaxations mediated by EP4 and/or EP2 receptors might involve a cAMP signalling pathway via Gs. Further, cAMP stimulates calcium activated $\mathrm{K}^{+}$channels, which is related to the PGE1-induced relaxation of human corporal smooth muscle (20).

An EP1 receptor agonist, ONO-DI-004, induced a slight contraction of the rabbit corpus cavernosum strips. The data suggest that the EP1 receptors might mediate contraction of the rabbit cavernosal smooth muscle. Since it is known that the activation of the EP1 receptors produces a contraction of the smooth muscle by increasing intracellular calcium (25) and that the EP1 receptors activate $\mathrm{Gq}$ protein to elevate the intracellular calcium in noncontractile cells (27), the present EP1 receptor mediated-cavernosal smooth muscle contraction might involve an increase in intracellular calcium via Gq.

It is known that the EP3 receptors are invloved in smooth muscle contraction (31) through a major signalling pathway of adenylyl cyclase inhibition via Gi $(8,25)$. However, the present study showed that the EP3 receptor agonist, ONO-AE-248, did not alter the contractility of the rabbit cavernosal smooth muscle as shown in Fig. 2. The EP3 receptors have four splicing variant isoforms $\mathrm{A}, \mathrm{B}, \mathrm{C}, \mathrm{D}$, in which the EP3A receptor is coupled to $\mathrm{Gi}$. The EP3B and EP3C receptors are coupled to Gs and cause an enhancement of the adenylyl cyclase activity. The EP3D receptor is coupled to Gq, in addition to $\mathrm{Gi}$ and Gs, and evokes a pertussis toxin-insensitive phosphatidyl inositol response $(18,23,24,33)$. Therefore, it is speculated that the EP3 receptor isoforms coupling to Gs might cause a relaxation of the smooth muscle, and reversely, the EP3 receptor isoforms coupling to $\mathrm{Gq}$ or $\mathrm{Gi}$ might elicit contaction. If the present responses to the EP3 receptor agonist are viewed from the speculation, they might be divided into two groups, a relaxant response and a contractile response. However, more studies are necessary to clear whether the EP3 receptors in the rabbit corpus cavaernosum smooth muscle mediate such dual effects.

Thus, the present studies demonstrated that ONOAE1-329, the EP4 receptor agonist, is a highly specific and effective drug to produce a relaxation of the rabbit corpus cavernosal smooth muscle. Recent$1 y$, in addition to the oral type-5 phosphodiesterase inhibitor sildenafil citrate, PGE1 has been intraurethraly administrated as a therapy for erectile dysfunction (28). Therefore, the present EP4 receptor agonist might be more effective for therapies of erectile dysfunction than PGE1 and PGE2.

In conclusion, the data presented demonstrated that the EP receptor subtypes played a role in regulating the contractility of the rabbit corpus cavernosum smooth muscle. The EP4 and/or EP2 receptors mediate relaxations, and EP4 relaxant system is profoundly higher than EP2 relaxant system. The relaxations mediated by the EP4 and/or EP2 receptors are performed independently from the NO/cGMP signalling pathway. The EP1 receptors mediate a slight contraction. The EP4 receptor agonist might provide a new strategy for pharmacological treatment of erectile dysfunction.

\section{Acknowledgment}

We are grateful to Ono Pharmaceutical Co. Ltd. 
(Osaka, Japan) for gifts of EP subreceptor agonists and/or antagonist. We also thank Miss Toshie Nimura for technical assistance. This work was supported by grant-in-aid for scientific research 16500258 from the ministiry of education, culture, sports, science and technology of Japan.

\section{REFERENCES}

1. Aboseif SR, Riemer RK, Stackl W, Lue TF and Tanagho EA (1993) Quantification of prostaglandin receotors in cavernous tissue of men, monkeys and dogs. Urol Int 50, 148-152.

2. An S, Yang J, Xia M and Goetzl EJ (1993) Cloning and expression of the EP2 subtype of human receptors for prostaglandin E2. Biochem Biophys Res Commun 197, 263-270.

3. Anderson K-E and Wagner G (1995) Physiology of penile erection. Physiol Rev 75, 191-236.

4. Anderson K-E (2001) Pharmacology of penile erection. Pharmacol Rev 53, 417-450.

5. Angulo J, Cuevas P, La Fuente JM, Pomerrol JM, Ruiz-Castane E, Puigvert A, Gabancho S, Fernandez A, Ney P and Saenz de Tejada I (2002) Regulation of human penile smooth muscle tone by prostanoid receptors. Br J Pharmacol 136, 23-30.

6. Basien L, Sawyer N, Grygorczyk R, Metters KM and Adam $M$ (1994) Cloning, functional expression and characterization of the human prostaglandin E2 receptor subtype. $J$ Biol Chem 269, 11873-11877.

7. Bivalacqua TJ, Champion HC, Hellstom WJG and Kadowitz PJ (2000) Pharmacotherapy for erectile dysfunction. Trends Pharmacol Sci 21, 484-489.

8. Boie Y, Stocco R, Sawyer N, Slipetz DM, Ungrin MD, Neuschafer-Rube F, Puschel GP, Metters KM and Abramovitz M (1997) Molecular cloning and characterization of the four rat prostaglandin E2 prostanoid receptor subtypes. Eur $J$ Pharmacol 340, 227-241.

9. Burnett AL, Lowenstein CJ, Bredt DS, Chang TS and Snyder SH (1992). Nitric oxide: a physiologic mediator of penile erection. Science 257, 401-403.

10. Cahn DJ, Melman A, Valcic M and Chriat GJ (1996) Folskolin: a promising new adjunct to intracavernous pharmacotherapy. J Urol 155, 1789-1794.

11. Coleman RA, Kennedy I, Humohrey PPA, Bunce K and Lumley P (1990) Prostanoids and their receptors. In: Comprehensive Medicinal Chemistry, Vol 3 (Hansch C, Sammes PG and Taylor JB, eds), pp 643-714, Pergamon Press, Oxford, UK.

12. Coleman RA, Grix SP, Head SA, Loutitt JP, Mallett A and Sheldrick RL (1994) A novel inhibitory prostanoid receptor in piglet saphenous vein. Prostaglandins 47, 151-168.

13. Coleman RA, Smith WL and Narumiya S (1994) VIII. International union of pharmacology. Classification of prostanoid receptors: properties, distribution, and structure of the receptors and their subtypes. Pharmacol Rev 46, 205-229.

14. Delpy E, Coste H and Gouville AC (1996) Effects of cyclic GMP elevation on isoprenaline-induced increase in cyclic AMP and relaxation in rat aortic smooth muscle: role of phosphodiesterase 3. Br J Pharmacol 119, 471-478.

15. Escrig A, Marin R and Mas M (1999) Repeated PGE1 treatment enhances nitric oxide and erection responses to nerve stimulation in the rat penis by upregulating constitutive NOS isofrms. J Urol 162, 2205-2210.

16. Gardiner PJ (1986) Characterization of prostanoid relaxant/ inhibitory receptors $(\psi)$ using a highly selective agonist, TR4979. Br J Pharmacol 87, 45-56.

17. Hedlund $\mathrm{H}$ and Andersson KE (1985) Contraction and relaxation induced by some prostanoids in isolated human penile erectile tissue and cavernous artery. J Urol 134, 1245-1250.

18. Irie A, Sugimoto Y, Namba T, Harazono A, Honda A, Watabe A, Negishi M, Narumiya S and Ichikawa A (1993) Third isoform prostaglandin-E-receptor EP3 subtype with different C-terminal tail coupling to both stimulation and inhibition of adenylate cyclase. Eur J Biochem 217, 313-318.

19. Kiriyama M, Ushikubi F, Kobayashi T, Hirata M, Sugimoto Y and Narumiya S (1997) Ligand binding specificities of the eight types and subtypes of the mouse prostanoid receptors expressed in Chinese hamster ovary cells. Br J Pharmacol 122, 217-224.

20. Lee SW, Wang HZ, Zhao W, Ney P, Brink PR and Christ GJ (1999) Prostaglandin E1 activates the large-conductance KCa channel in human corporal smooth muscle cells. Int $J$ Impot Res 11, 189-199.

21. Lin JS, Lin YM, Jou YC and Cheng JT (1995) Role of cyclic adenosine monophosphate in prostaglandin E1-induced penile erection in rabbits. Eur Urol 28, 259-265.

22. Moreland RB, Nehra A, Goldstein I and Traish A (1999) The role of prostsglandin $\mathrm{E}$ as determined by expression of functional prostaglandin $\mathrm{E}$ receptors in human corpus cavrnosum. J Urol 161(Suppl), 218.

23. Namba T, Sugimoto Y, Negishi M, Irie A, Ushikubi F, Kakizuka A, Ito S, Ichiwaka A and Narimura S (1993) Alternative splicing of C-terminal tail of prostaglandin $\mathrm{E}$ receptor subtype EP3 determines G-protein specificity. Nature 365, 166170.

24. Narumiya S, Sugimoto Y and Ushifubi F (1999) Prostanoid receptors: structures, properties, and functions. Physiol Rev 79, 1193-1226.

25. Negishi M, Sugimoto Y and Ichikawa A (1995) Molecular mechanism of divers actions of prostanoid receptors. Biochem Biophys Acta 1259, 109-120.

26. Nials AT, Vardey CJ, Denyer LH, Thomas M, Sparrow SJ, Shephard GD and Coleman RA (1993) AH13205, a selective prostanoid EP2-receptor agonist. Cardiovasc. Drug Rev 11, $165-179$.

27. Okuda-Ashitaka E, Sakamoto K, Ezashi T, Miwa K, Ito S and Hayaishi O (1996) Suppression of prostaglandin E receptor signaling by the variant form of the EP1 subtype. $J$ Biol Chem 271, 31255-31261.

28. Padma-Nathan H, Hellstom WJ, Kaiser FE, Labasky RF, Lue TF, Nolten WE, Norwood PC, Peterson CA, Shabshigh R and Tam PY (1997) Treatment of men with erectile dysfunction with transurethral alprostadil. Medicated Urethral System for Erection (MUSE) Study Group. $N$ Engl J Med 336, $1-7$.

29. Palmer LS, Valcic M, Melman A, Giraldi AM, Wagner G and Christ GJ (1994) Characterization of cyclic AMP accumulation in cultured human corpus cavernosum smooth muscle cells. J Urol 152, 1308-1314.

30. Porst H (1996) The rationale for prostaglandin E1 in erectile failure: a survey for worldwide experience. $J$ Urol 155, 802815.

31. Qian YM, Jones RL, Chan KM, Stock AI and Ho JK (1994) Potent contractile actions of prostanoid EP3 receptor agonists on human isolated pulmonary artery. Br J Pharmacol 113, 369-374.

32. Sato $\mathrm{M}$ and Kawatani $\mathrm{M}$ (2002) Effects of noradrenaline on cytosolic concentrations of $\mathrm{Ca}^{2+}$ in cultured corpus caverno- 
sum smooth muscle cells of the rabbit. Neurosci Lett 324, 89-92.

33. Sugimoto Y, Negishi M, Hayashi Y, Namba T, Honda A, Watabe A, Hirata M, Narumita S and Ichikawa A (1993) Two isoforms of the EP3 receptor with different carboxyl-terminal domains: identical ligand binding properties and different coupling properties with Gi proteins. J Biol Chem 268, 2712-2718.

34. Suzawa T, Miyaura C, Inada M, Maruyama T, Sugimoto $\mathrm{Y}$, Ushikubi F, Ichikawa A, Narimita S and Suda T (2000) The role of prostaglandin E receptor subtypes (EP1, EP2, EP3, and EP4) in bone resorption: an analysis using specific ago- nists for the respective EPs. Endocrinology 141, 1554-1559.

35. Tand L, Loutzenhiser K and Loutzenhiser R (2000) Biphasic actions of prostaglandin E2 on the renal afferent arteriole: role of EP3 and EP4 receptors. Circ Res 86, 663-670.

36. Traish AM, Moreland RB, Gallant C, Huang YH and Goldstein I (1997) G-protein coupled recptor agonists augment adenylyl cyclase activity induced by forskolin in human corpus cavernosum smooth muscle cells. Recept Signal Transduct 7, 121-132.

37. Wise H, Wong YH and Jones RL (2002) Prostanoid signal integration and cross talk. Neurosignals 11, 20-28. 